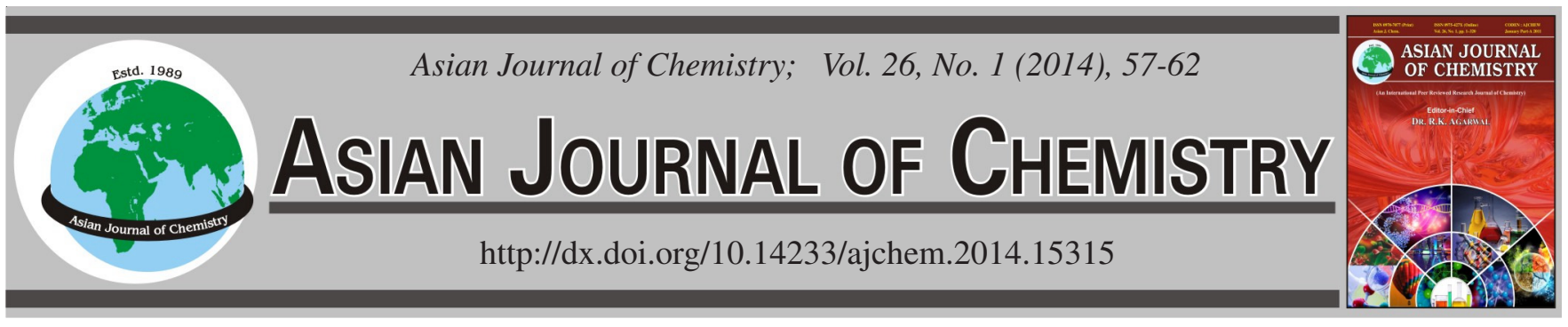

\title{
Spectrophotometric and Spectrofluorometric Determination of Doxazosin Mesylate in Tablets via Eosin Y
}

\author{
Reda A. Ammar ${ }^{1,2}$, Amina M. El-Brashy $^{1, *}$ and Tafla N. Al-Sahly ${ }^{1}$
}

${ }^{1}$ Department of Chemistry, College of Science, King Saud University, P.O. Box 22452, Riyadh 11495, Saudi Arabia

${ }^{2}$ Department of Chemistry, College of Science, Al-Azhar University, Cairo, Egypt

*Corresponding author: E-mail: aalbrashy@ksu.edu.sa

Received: 11 February 2013;

Accepted: 25 June 2013;

Published online: 26 December 2013;

AJC-14473

\begin{abstract}
Doxazosin mesylate, an inhibitor of $\alpha$-adrenergic receptors, was determined through formation of ion-pair complex with Eosin Y reagent in acetate buffer at $\mathrm{pH}$ 3. Two simple and sensitive spectroscopic methods were suggested. The first method based on spectrophotometric measurement of the complex at $547 \mathrm{~nm}$ and the second one based on spectrofluorimetric quenching measurement of the complex at 570 $\mathrm{nm}$, after excitation at $340 \mathrm{~nm}$. Under the optimum conditions, doxazosin mesylate was determined in the range of $2-14 \mu \mathrm{g} \mathrm{mL}^{-1}$ and $1-10 \mu \mathrm{gL}^{-1}$ by the spectrophotometric and spectrofluorimetric methods respectively, with good accuracy and precision in pure form. The method was successfully applied for determination of doxazosin mesylate in its tablets. All the results were statistically compared with that obtained by a reference method and subjected to validation analysis according to International Conference on Harmonization.
\end{abstract}

Keywords: Doxazosin mesylate, Eosin Y, Fluorometry, Quenching, Spectrophotometry, Dosage forms.

\section{INTRODUCTION}

Doxazosin mesylate is a quinazoline compound that is selective inhibitor of the $\alpha$-1 subtype of $\alpha$-adrenergic receptor A, benign prostatic hyperplasia (BPH) and used in treatment of hypertension. Doxazosin mesylate may be used in all BPH patients whether hypertensive or normotensive ${ }^{1}$.<smiles>COc1cc2nc(N3CCN(C(=O)C4COc5ccccc5O4)CC3)nc(N)c2cc1OC</smiles>

Various methods have been published for the determination of doxazosin mesylate either by itself or in pharmaceutical preparations and biological fluids. The methods included liquid chromatography ${ }^{2-5}$, high performance thin layer chromatography $^{6}$, flow injection with UV detection ${ }^{7}$ and polarography ${ }^{8}$. The only reported spectrophotometric methods were that either measuring doxazosin absorbance at $248 \mathrm{~nm}$ in methanol ${ }^{9}$, first derivative in presence of its degraded product ${ }^{10}$ or reacting with bromocresol green and bromothymol blue and measuring the color after extraction the complex in chloroform ${ }^{11}$. Also, another spectrophotometric method was used for determination of doxazosin mesylate which depended on reaction with dichlorodicyano- $p$-benzoquinane (DDQ) or tetracyanoquinodimethane (TCNQ) which formed charge-transfer complexes in acetonitrile ${ }^{11}$.

To the best of our knowledge, up to the present time, nothing has been reported concerning determination of doxazosin mesylate with eosin either by spectrophotometry or spectrofluorometry. The aim of the present work is to study simple, sensitive spectrophotometric and quantitative quenching spectrofluorometric methods for determination of doxazosin mesylate in pure form and in its tablets. The proposed methods are simple and not required any sophisticated instrumentation that precluded their use or using multiple extraction in organic solvents. They are recommended for quality control and routine analysis where time, cost effectiveness and highly specificity of analytical techniques are of great importance.

\section{EXPERIMENTAL}

The spectrophotometric measurements were performed using Ultrospec 2000, UV/visible spectrophotometer, Biochrom Ltd., Cambridge, U.K., equipped with $1 \mathrm{~cm}$ matched quartz cells. Spectrofluorometric measurements were performed using spectrofluorimeter (Jasco model FP6200, Japan) equipped with Xenon discharge lamp and $1 \mathrm{~cm}$ quartz cell. The excitation and emission slit controls set at $6 \mathrm{~nm}$. 
All the chemicals used were of analytical reagent grade and the water was always double distilled water. Doxazosin mesylate was kindly supplied by Pfizer Co., Cairo (Egypt). It was used as received and its purity was $99.96 \%$. Aqueous $4 \times$ $10^{-3} \mathrm{M}$ solution of Eosin Y (Sigma) was prepared. Acetate buffer solution of $\mathrm{pH} 2.5-5$, using $0.4 \mathrm{M}$ acetic acid (BDH, Germany) and $0.4 \mathrm{M}$ sodium acetate (BDH, Germany) solutions were prepared by mixing various volumes of acetic acid and sodium acetate ( $0.4 \mathrm{M}$ for each) to the required $\mathrm{pH}$ value (2.5-5).

Doxazosin mesylate tablets were purchased from commercial markets, they included: (a) Cardura, $4 \mathrm{mg}$ tablets; containing $4 \mathrm{mg}$ doxazosin (as a base) per tablet, manufactured by Pfizer Egypt SAE Cairo, ARE under Authority of Pfizer INC. USA. Batch No. 1202. (b) Dosin 4 mg tablets, containing 4 mg doxazosin as mesylate per tablet manufactured by Egyptian Int. Pharmaceutical Industries Co., $10^{\text {th }}$ of Ramadan City, Egypt, Batch No. 2250.

Stock solution: $50 \mathrm{mg}$ of doxazosin mesylate was dissolved in $100 \mathrm{~mL}$ of double distilled water. Serial dilution was prepared using water as solvent.

Spectrophotometric method: Accurately measured aliquots of doxazosin mesylate in the concentration range 2- $14 \mu \mathrm{g} \mathrm{mL}^{-1}$ were transferred into a series of $10 \mathrm{~mL}$ volumetric flasks and diluted to about $7 \mathrm{~mL}$ with distilled water. Eosin Y, $0.6 \mathrm{~mL}$ of $4 \times 10^{-3} \mathrm{M}$ solution was then added and the mixtures were mixed well before the addition of $1.5 \mathrm{~mL}$ of $0.4 \mathrm{M}$ acetate buffer ( $\mathrm{pH} 3$ ) to each flask. The mixtures were diluted to volume with distilled water and the absorbance was measured at $547 \mathrm{~nm}$ against an appropriate blank prepared simultaneously. The calibration curve between the absorbance and the concentration of doxazosin mesylate $\left(\mu \mathrm{g} \mathrm{mL}^{-1}\right)$ was plotted or the regression equation was derived.

Spectrofluorometric method: Accurately measured aliquots of doxazosin mesylate covering the concentration range $1-10 \mu \mathrm{g} \mathrm{mL}^{-1}$ were transferred into a series of $10 \mathrm{~mL}$ volumetric flasks and diluted to about $7 \mathrm{~mL}$ with distilled water. $0.6 \mathrm{~mL}$ of $4 \times 10^{-3} \mathrm{M}$ solution of eosin $\mathrm{Y}$ was then added and the mixtures were mixed well followed by addition of $1.5 \mathrm{~mL}$ of $0.4 \mathrm{M}$ acetate buffer of $\mathrm{pH} 3$. The fluorescence intensities of the solutions at $570 \mathrm{~nm}$ after excitation at $340 \mathrm{~nm}$ were measured and the decrease in fluorescence intensity (DF) versus the final concentration of doxazosin mesylate in $\mu \mathrm{g}$ $\mathrm{mL}^{-1}$ was plotted to obtain the calibration curve, alternatively, the corresponding regression equation was derived.

Procedure for dosage forms: An accurately weighed quantity of the pulverized tablets equivalent to $20 \mathrm{mg}$ of doxazosin mesylate were transferred to a $100 \mathrm{~mL}$ volumetric flask, $80 \mathrm{~mL}$ of distilled water were added and sonicated to about $0.5 \mathrm{~h}$. The volume was completed with water and filtered. Aliquots of this solution were transferred into a series of $10 \mathrm{~mL}$ volumetric flasks and the analysis was completed as previously mentioned under spectrophotometric or spectrofluorometric method. The nominal content of the tablets was calculated either from a previously plotted calibration curve or using the regression equations.

\section{RESULTS AND DISCUSSION}

Eosin (tetrabromofluorescein) is a yellowish red dye with green fluorescence has been used as ion-pairing agent for the spectrophotometric and spectrofluorometric determination of some amino compounds ${ }^{12-14}$. It was found to be quenched by formation of a stable complex with doxazosin mesylate at $\mathrm{pH} 3$. The formed complex is mainly due to the electrostatic interaction between doxazosin and anionic functional group of eosin at acidic solution ( $\mathrm{pH}$ 2.5-3.8). The main purpose of this study was to establish simple spectrophotometric and spectrofluorometric methods for the determination of doxazosin mesylate in its tablets without prior extraction. Both methods were developed and simply based on a binary complex formation between doxazosin and eosin Y. The ion-pair associate of doxazosin and eosin was slightly soluble in water, but under the optimized experimental conditions, it became freely soluble in water and did not need an extraction into organic solvents nor the addition of non-ionic surfactants. The ionpair associate exhibited absorption maxima at $547 \mathrm{~nm}$ (Fig. 1) while the quenching effect appears in Fig. 2, at emission wavelength $570 \mathrm{~nm}$ after excitation at $340 \mathrm{~nm}$.

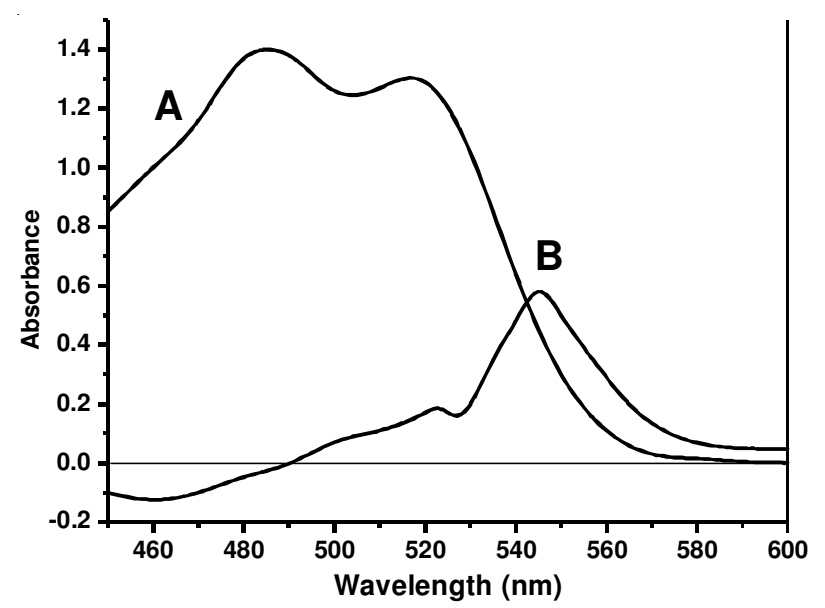

Fig. 1. Absorption spectra of (A) blank Eosin $\left(4 \times 10^{-5} \mathrm{M}\right)$ and (B) its binary complex with $8 \mu \mathrm{g} \mathrm{mL}^{-1}$ doxazosin mesylate in acetate buffer, at $\mathrm{pH} 3$

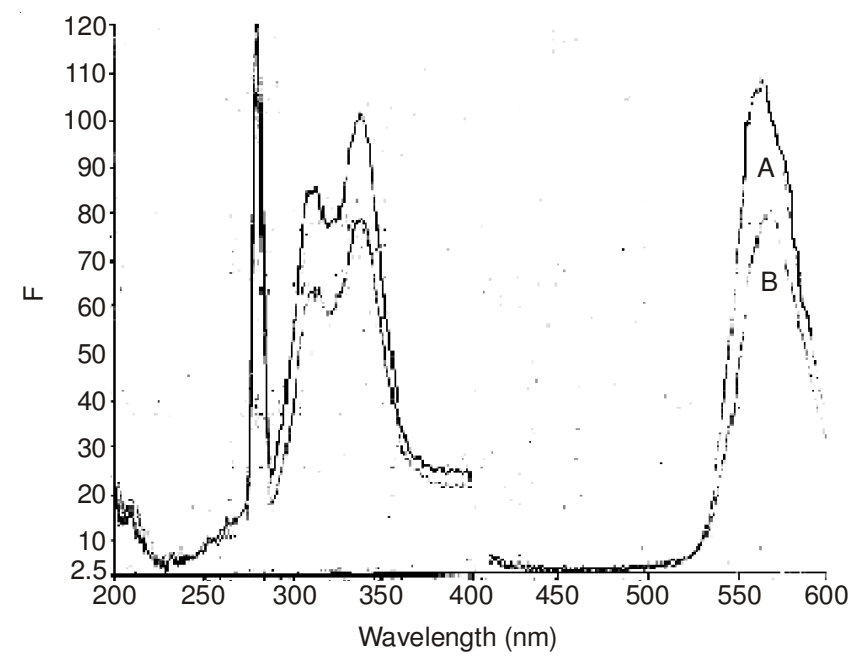

Fig. 2. Excitation and emission spectra resulted from reaction of doxazosin mesylate and Eosin. (A) blank Eosin $\left(4 \times 10^{-4} \mathrm{M}\right)$ and $(\mathrm{B})$ reaction product of Eosin $\left(4 \times 10^{-4} \mathrm{M}\right)$ and $3 \mu \mathrm{g} / \mathrm{mL}$ doxazosin mesylate in acetate buffer,at $\mathrm{pH} 3$

Optimization of reaction condition: Being slightly soluble in aqueous solution, the ion-pair of doxazosin and eosin is too unstable for the produced colour to be accurately and 
precisely measured. Therefore, trials to increase complex stability and to prevent precipitate formation were made. It was found that keeping the sample concentrations at maximum dilution before addition of eosin solution had greatly increased complex stability with complete prevention of precipitate formation.

The addition of non-ionic surfactant as well as poly(vinyl alcohol) which reported in literature ${ }^{15,16}$ to stabilize and solubilize this type of complexes have no effect in present study. Consequently, according to the above mentioned procedures, the formation of the drug-dye color complex was instant and the color development was complete within a few seconds after adding eosin. An additional advantage was that the intensity of the final color was stable for a long period, more than $72 \mathrm{~h}$, with no precipitation of the complex.

Heating at higher temperature had no effect on the rate of the reaction, conversely, it caused complex breakdown and weakened the color intensity. Therefore, room temperature was chosen as optimum for the assay procedures. In this study, order of addition of reagent was found to be necessary for good precision.

The concentration of the reagent and the $\mathrm{pH}$ of the medium had been optimized by the two suggested procedures to achieve the best sensitivity and linearity with maximum stability.

Effect of pH: The effect of pH on the absorbance (A) or quenching effect $(\Delta \mathrm{F})$ of the binary complex of eosin and doxazosin was studied over $\mathrm{pH}$ range 1.0-6.5. Optimum absorbance values and maximum quenching were achieved at $\mathrm{pH}$ 3. $1.5 \mathrm{~mL}$ of $0.4 \mathrm{M}$ acetate buffer was found to be sufficient to bring the $\mathrm{pH}$ into optimum range (Fig. 3). For the highest color intensity, quenching and maximum precision, the buffer solution should be added after mixing the drug-dye solution at neutral $\mathrm{pH}$.

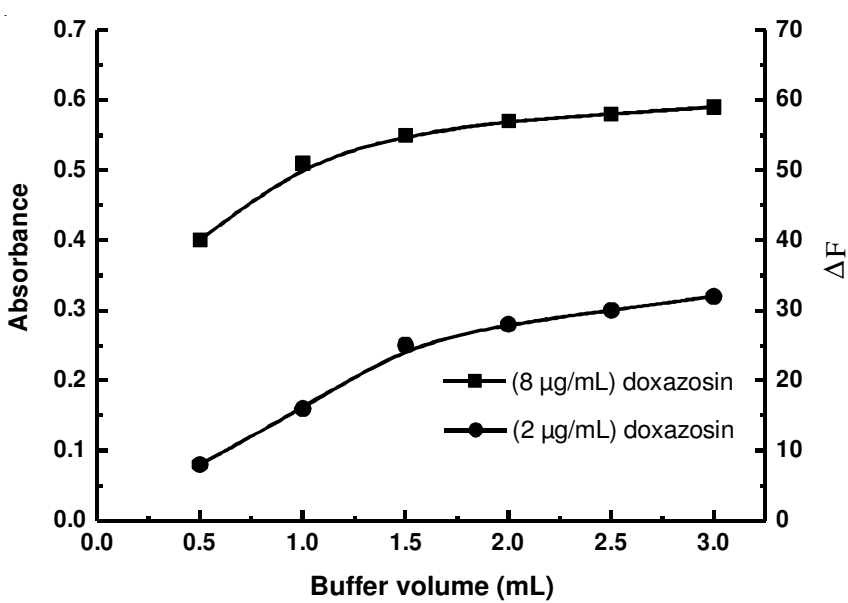

Fig. 3. Effect of volume of acetate buffer $(\mathrm{pH}=3)$ on the ion-pair complex of doxazosin and eosin Y ( $\mathbf{\square}$ spectrophotometry, $\bullet$ spectrofluorometry)

Effect of reagent concentration: The optimum reagent concentration was determined by adding various volumes of $4 \times 10^{-3} \mathrm{M}$ Eosin Y solution to a fixed concentration of doxazosin mesylate. Absorbance obtained at $547 \mathrm{~nm}$ and quenching values at 570/340 nm were shown in Fig. 4, from which it was found that $0.5-0.6 \mathrm{~mL}$ of $4 \times 10^{-3} \mathrm{M}$ Eosin solution

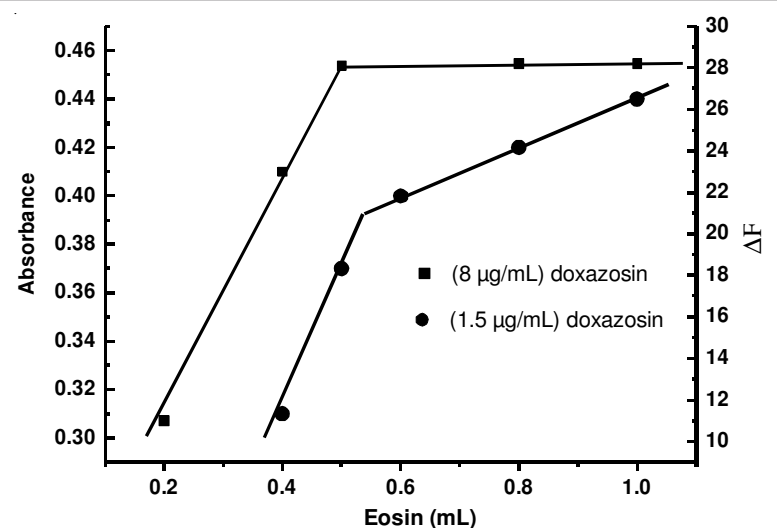

Fig. 4. Effect of Eosin $\mathrm{Y}$ volume on the ion-pair complex of Doxazosin and Eosin Y ( $\mathbf{\square}$ spectrophotometry, $\bullet$ spectrofluorometry)

was enough to develop the absorbance and quenching values at their maximum intensities.

Composition of the ion-pair associate: The composition of the ion-pair associate was established by Job's method of continuous variation ${ }^{17}$ and molar ratio method ${ }^{18}$ using equimolar solution of doxazosin mesylate and eosin, by application of the spectrophotometric method. The results obtained were shown in Figs. 5 and 6, respectively and indicated that the composition of the associate $(1: 2)$ for doxazosin and eosin respectively, due to the active primary amino group and one of the tertiary group (Scheme-I).

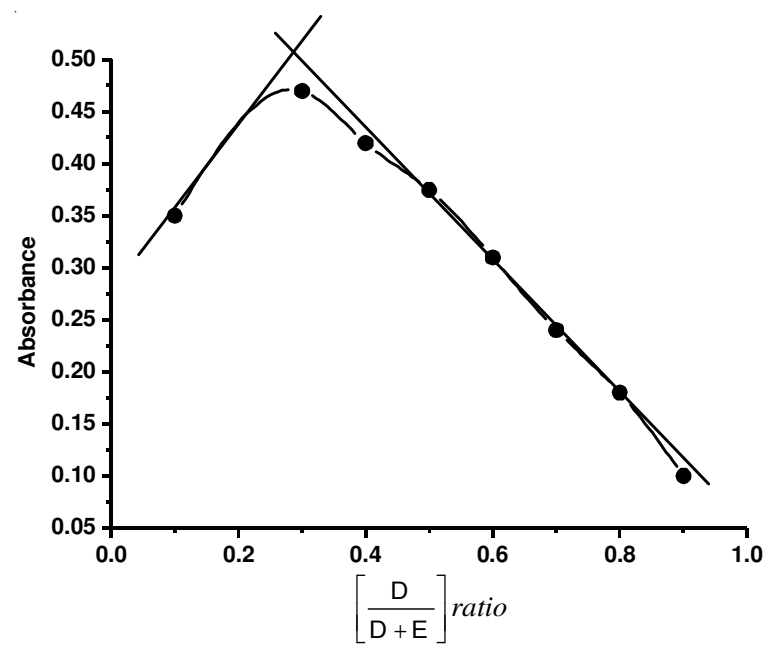

Fig. 5. Continuous variation plot of the ion-pair associate complex of doxazosin mesylate and Eosin $\mathrm{Y}$, each concentration is $1 \times 10^{-3} \mathrm{M}$

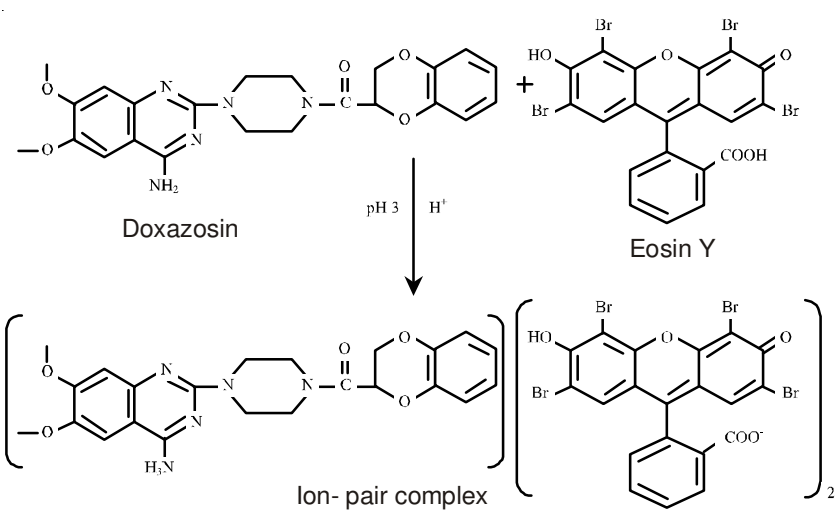

Scheme-I: Proposal mechanism for the reaction of doxazosin-Eosin Y 


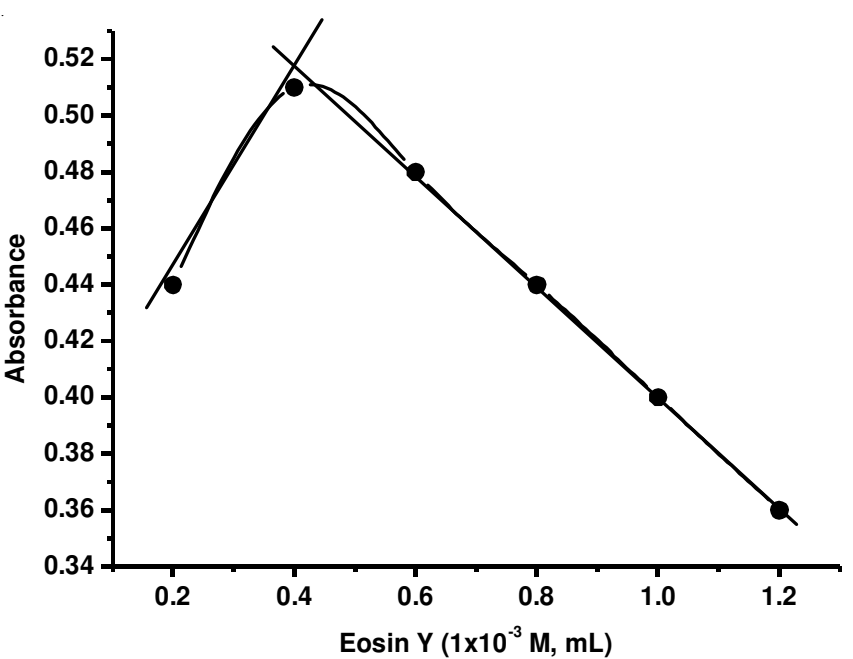

Fig. 6. Mole ratio plot of the ion-pair associate complex of doxazasin mesylate and Eosin Y, $2 \mathrm{~mL}$ of doxazosin mesylate of $1 \times 10^{-3} \mathrm{M}$ were used

Validation methods: Under the experimental conditions described above, the calibration graphs for doxazosin mesylate and eosin Y by the spectrophotometric and spectrofluorometric methods were evident in the concentration ranges of 2-14 $\mu \mathrm{g}$ $\mathrm{mL}^{-1}$ and $1-10 \mu \mathrm{g} \mathrm{mL}^{-1}$ for both methods, respectively. Regression equations, intercepts, slopes and correlation coefficients for the calibration data by the two methods were presented in Table-1. Linear regression analysis of the data gave the following equations:

$$
\begin{aligned}
\mathrm{A}=0.0153+0.0623 \mathrm{c} & (\mathrm{r}=0.9992) \\
\Delta \mathrm{F}=-0.575+12.818 \mathrm{c} & (\mathrm{r}=0.99997)
\end{aligned}
$$

where (A) is the absorbance at $547 \mathrm{~nm}, \Delta \mathrm{F}$ is the quenching in the fluorescence intensity. $\Delta \mathrm{F}$ is the native fluorescence of eosin solution $\left(\mathrm{F}^{\circ}\right)$-fluorescence of the reaction protect $(\mathrm{F}),(\mathrm{C})$ is the concentration of the drug in $\mu \mathrm{g} \mathrm{mL}^{-1}$ and (r) is the correlation coefficient.

Alternatively, by applying Stern-Volmer equation ${ }^{19}$, it was found that:

$$
\mathrm{F}^{\circ} / \mathrm{F}=0.70422+0.2566 \mathrm{Q} \quad(\mathrm{r}=0.99925)
$$

where $\mathrm{F}^{\mathrm{o}}$ is the native fluorescence of eosin solution, $\mathrm{F}$ is the fluorescence of the reaction product after addition of Q-amount of the drug. (Q) is the quenching concentration of the drug in $\mu \mathrm{g} \mathrm{mL} \mathrm{L}^{-1}$.

Limit of quantitation and limit of detection: The limit of quantitation (LOQ) is the lowest concentration that can be measured whereas the limit of detection (LOD) was determined by establishing the minimum level at which the analyte can be reliably detected. They were calculated according to $\mathrm{ICH}$ Q2 (R1) recommendation ${ }^{20}$ :

$$
\begin{aligned}
\mathrm{LOQ} & =10 \mathrm{Sa} / \mathrm{b} \\
\mathrm{LOD} & =3.3 \mathrm{Sa} / \mathrm{b}
\end{aligned}
$$

where, $\mathrm{Sa}$ is the standard deviation of the intercept of the calibration curve and $\mathrm{b}$ is the slope of the calibration curve. LOQ values were found to be 1.191 and $0.241 \mu \mathrm{g} \mathrm{mL}^{-1}$ while LOD values were found to be 0.393 and $0.0784 \mu \mathrm{g} \mathrm{mL}^{-1}$ for

\begin{tabular}{|c|c|c|}
\hline Parameter & $\begin{array}{l}\text { Spectrophoto- } \\
\text { metric method }\end{array}$ & $\begin{array}{l}\text { Spectrofluoro- } \\
\text { metric method }\end{array}$ \\
\hline Concentration range $\left(\mu \mathrm{g} \mathrm{mL}^{-1}\right)$ & $2-14$ & $1-10$ \\
\hline Correlation Coefficient (r) & 0.9992 & 0.99997 \\
\hline Intercept & 0.0153 & -0.575 \\
\hline Slope & 0.0623 & 12.818 \\
\hline S.D & 1.616 & 1.10 \\
\hline R.S.D. (\%) & 1.614 & 1.098 \\
\hline Error $(\%)$ & 0.66 & 0.449 \\
\hline $\mathrm{Sy} / \mathrm{x}^{\mathrm{a}}$ & 0.0104 & 0.397 \\
\hline $\mathrm{Sa}^{\mathrm{b}}$ & 0.00742 & 0.309 \\
\hline $\mathrm{Sb}^{\mathrm{c}}$ & 0.001 & 0.0508 \\
\hline $\operatorname{LOD}\left(\mu \mathrm{g} \mathrm{mL}^{-1}\right)^{\mathrm{d}}$ & 0.393 & 0.0794 \\
\hline $\operatorname{LOQ}\left(\mu \mathrm{g} \mathrm{m} \mathrm{L}^{-1}\right)^{\mathrm{e}}$ & 1.191 & 0.241 \\
\hline \\
\hline
\end{tabular}
the spectrophotometric and spectrofluorometric methods, respectively.
TABLE-1

PERFORMANCE DATA FOR THE PROPOSED METHODS

Precision and accuracy: The percentage recoveries of doxazosin mesylate in pure form and in its commercial tablets Cardura and Dosin by the proposed methods compared with that obtained by reference method ${ }^{11}$ were given in Table-2. The reference method ${ }^{11}$ depended on formation of chargetransfer complex between doxazosin mesylate and tetracyanoqauinodimethane (TCNQ) and measuring the absorbance at 745 or $845 \mathrm{~nm}$ in acetonitrile. The results of the proposed methods were statistically compared with those obtained using the reference method ${ }^{11}$. Statistical analysis of the results ${ }^{21}$ using student's t-test and variance ratio F-test, revealed that no significant difference between the performance of the proposed and reference methods regarding the accuracy and precision, respectively (Table-2). Moreover, no extraction was needed and little amounts were used for determination. The proposed methods were further applied to the determination of doxazosin mesylate in its tablets using the standard addition method. The method was performed by addition of successive amounts of standard doxazosin mesylate to a fixed amount of tablets and the absorbance or $\Delta \mathrm{F}$ values were plotted versus amounts added. By extrapolation of the straight line obtained, the amount of doxazosin in tablets could be determined as indicated in Figs. 7 and 8. The percentage recoveries using the standard addition method were given in Table-3. Common tablet excipients such as talc, lactose, starch and magnesium stearate did not interfere with the assay.

The formation constant of the reaction product was calculated according to the following equation ${ }^{22}$ :

$$
K_{f}=\frac{A / A M}{\left[(1-A / A M)^{n+1}\right] C^{n} C^{n}}
$$

where $\mathrm{A}$ and $\mathrm{Am}$ are the observed maximum absorbance and the absorbance obtained from the extrapolation of the two lines obtained from Job's continuous variation method respectively; $\mathrm{n}$ is the number of molecules of the reagent in the reaction product, the ratio is 1:2 (doxazosin:eosin respectively); $\mathrm{C}$ is the molar concentration of the drug used in Job's continuous variation method. Using the above equation $\mathrm{K}_{\mathrm{f}}$ was found to be $4.6 \times 10^{11}$. 


\begin{tabular}{|c|c|c|c|c|c|c|}
\hline \multirow[b]{3}{*}{ Compound } & $\begin{array}{l}\text { ON OF THE PR } \\
\text { DOXAZOSII }\end{array}$ & $\begin{array}{r}\text { TA } \\
\text { SED AND RE } \\
\text { ESYLATE IN }\end{array}$ & $\begin{array}{l}\text { E-2 } \\
\text { RENCE METH } \\
\text { JRE FORM ANI }\end{array}$ & $\begin{array}{l}\text { S FOR THE A } \\
\text { v TABLETS }\end{array}$ & LYSIS OF & \\
\hline & \multicolumn{2}{|c|}{ Spectrophotometric } & \multicolumn{2}{|c|}{ Spectrofluorometric } & \multicolumn{2}{|c|}{ Reference [12] } \\
\hline & $\begin{array}{l}\text { Amount taken } \\
\left(\mu \mathrm{g} \mathrm{mL}^{-1}\right)\end{array}$ & Found (\%) & $\begin{array}{l}\text { Amount taken } \\
\left(\mu \mathrm{gL}^{-1}\right)\end{array}$ & Found $(\%)^{*}$ & $\begin{array}{l}\text { Amount taken } \\
\left(\mu \mathrm{g} \mathrm{mL} \mathrm{mL}^{-1}\right)\end{array}$ & Found (\%) \\
\hline Doxazosin mesylate & 2 & 101.02 & 1 & 98.95 & 10 & 99.67 \\
\hline \multirow[t]{5}{*}{ (pure form) } & 4 & 100.64 & 2 & 100.60 & 20 & 100.48 \\
\hline & 8 & 99.46 & 4 & 99.57 & 30 & 101.24 \\
\hline & 10 & 99.62 & 6 & 99.64 & 40 & 100.06 \\
\hline & 12 & 98.86 & 8 & 100.31 & & \\
\hline & 14 & 100.34 & 10 & 100.42 & & \\
\hline Mean \pm S.D. & & $99.99 \pm 0.81$ & & $99.92 \pm 0.63$ & & $100.36 \pm 0.67$ \\
\hline Student's t-test & & $0.75(2.31)$ & & $1.05(2.31)$ & & \\
\hline Variance ratio & & $1.46(9.01)$ & & $1.13(5.41)$ & & \\
\hline Cardura Tablets & 4 & 98.72 & 2 & 99.84 & 10 & 99.24 \\
\hline \multirow[t]{3}{*}{ (4 mg doxazosin /tab.) } & 6 & 98.39 & 4 & 99.26 & 20 & 98.25 \\
\hline & 8 & 98.74 & 6 & 98.98 & 30 & 98.14 \\
\hline & 10 & 99.26 & 8 & 99.04 & 40 & 99.45 \\
\hline Mean \pm S.D. & & $98.78 \pm 0.36$ & & $99.18 \pm 0.52$ & & $98.77 \pm 0.67$ \\
\hline Student's-t-test & & $0.03(2.31)$ & & $0.96(2.31)$ & & \\
\hline Variance ratio & & $3.46(9.28)$ & & $1.64(9.28)$ & & \\
\hline Dosin Tablets & 4 & 99.84 & 2 & 98.96 & 10 & 98.88 \\
\hline \multirow[t]{3}{*}{4 mg Doxazosin mesylate/tab. } & 6 & 98.96 & 4 & 99.10 & 20 & 99.80 \\
\hline & 8 & 99.68 & 6 & 98.93 & 30 & 98.65 \\
\hline & 10 & 99.34 & 8 & 99.50 & 40 & 98.92 \\
\hline Mean \pm S.D. & & $99.46 \pm 0.39$ & & $99.12 \pm 0.26$ & & $99.06 \pm 0.51$ \\
\hline Student's-t-test & & $1.25(2.31)^{*}$ & & $0.21(2.31)$ & & \\
\hline Variance ratio & & $1.68(9.28)$ & & $3.72(9.28)$ & & \\
\hline
\end{tabular}

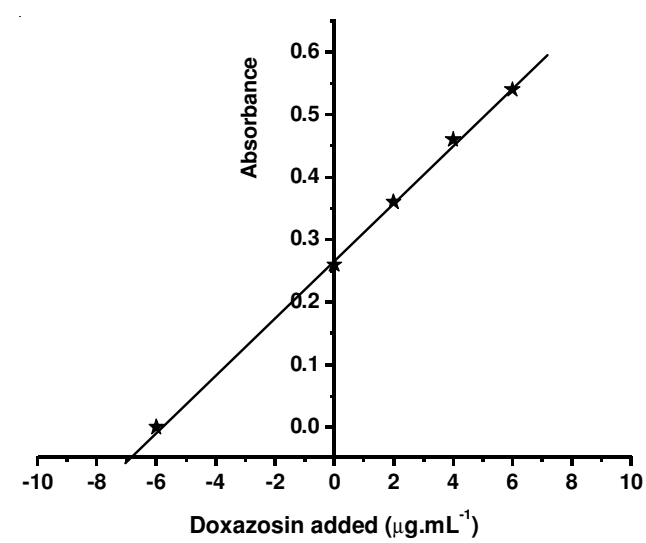

Fig. 7. Standard addition spectrophotometric method $(6 \mu \mathrm{g} / \mathrm{mL}$ doxazosin in Cardura tablets)

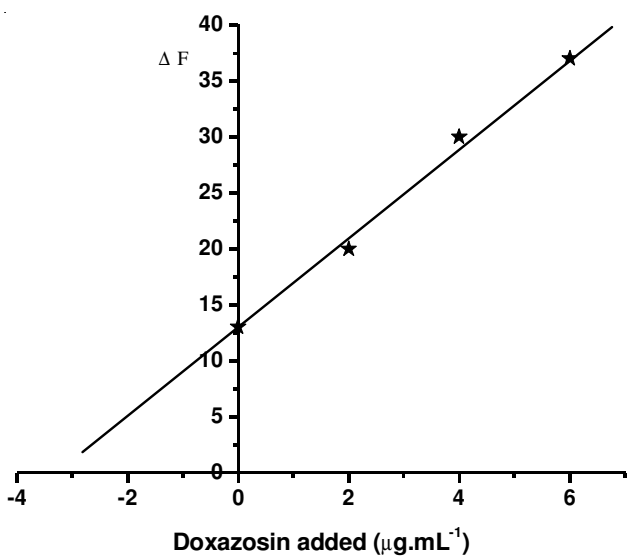

Fig. 8. Standard addition spectrophotometric method $(3 \mu \mathrm{g} / \mathrm{mL}$ doxazosin in Dosin tablets)

\section{Conclusion}

Eosin $\mathrm{Y}$ was chosen as a complexing agent obtaining water soluble ion-pair associate which has a measurable bathochromic shift. This paper describes two sensitive spectrophotometric and spectroflourometric procedures for the determination of doxazosin mesylate in its tablets dosage form, using eosin as an complexing agent without interference from common tablet excepients. Hence, they can be applied for the routine quality control of the studied drug either in bulk or in its corresponding dosage forms.

Another advantage of the proposed methods, from the economic point of view, is their simplicity, rapidity and they are inexpensive, using water as the dilution solvent. Moreover, they are less time-consuming and do not require various elaboration treatment and tedious extraction procedures. In addition, satisfactory sensitivity (1-2 $\mu \mathrm{g} \mathrm{mL}^{-1}$ ) and reproducibility of the proposed suggested methods were obtained compared to the reference method ${ }^{11}$, which required not less than $10 \mu \mathrm{g} \mathrm{mL}^{-1}$ to be determined by charge-transfer complex using tetracyanoquinodimethane (TCNQ) reagent. The convenience and simplicity, make the proposed spectrophotometric and spectrofluorometric methods applicable for routine quality control of doxazosin mesylate in pure form and tablets and good alternative to the other methods using organic solvents or with high cost.

\section{ACKNOWLEDGEMENTS}

The authors extended their appreciation to the Deanship of Scientific Research at King Saud University for funding the work through the research group project RGP-VPP-062. 


\begin{tabular}{|c|c|c|c|c|}
\hline \multirow{3}{*}{ Preparation } & \multicolumn{4}{|c|}{$\begin{array}{l}\text { TABLE-3 } \\
\text { PPLICATION OF THE PROPOSED METHOD FOR DETERMINATION OF DOXAZOSIN } \\
\text { MESYLATE IN TABLETS BY STANDARD ADDITION METHOD }\end{array}$} \\
\hline & \multicolumn{2}{|c|}{ Spectrophotometric } & \multicolumn{2}{|c|}{ Spectrofluorometric } \\
\hline & Amount taken $\left(\mu \mathrm{g} \mathrm{mL}^{-1}\right)$ & Found $(\%)^{*}$ & Amount taken $\left(\mu \mathrm{g} \mathrm{mL}^{-1}\right)$ & Found (\%) \\
\hline Cardura Tablets & 3 & 101.23 & 3 & 98.88 \\
\hline \multirow[t]{3}{*}{ (4 mg dox./tab.) } & 6 & 100.45 & 5 & 100.62 \\
\hline & 9 & 99.03 & 7 & 100.34 \\
\hline & 12 & 100.78 & 8 & 99.84 \\
\hline Mean \pm S.D & & $100.37 \pm 0.95$ & & $99.92 \pm 0.77$ \\
\hline Dosin Tablets & 3 & 100.25 & 3 & 100.60 \\
\hline (4 mg doxazosin & 6 & 99.42 & 5 & 99.85 \\
\hline mesylate /tab. & 9 & 101.04 & 7 & 99.48 \\
\hline & 12 & 100.84 & 8 & 98.65 \\
\hline Mean \pm S.D & & $100.39 \pm 0.73$ & & $99.65 \pm 0.81$ \\
\hline
\end{tabular}

\section{REFERENCES}

1. Health Mash, www.druglib.com; www.mayoclinic.com

2. Y.J. Kim, Y. Lee, M.J. Kang, J.S. Huh, M. Yoon, J. Lee and Y.W. Choi, Biomed. Chromatogr., 20, 1172 (2006).

3. N. Ma, W. Liu, H. Li, B. Chen, Y. Zhu, X. Liu, F. Wang, D. Xiang and B. Zhang, J. Pharm. Biomed. Anal., 43, 1049 (2007).

4. M. Erceg, M. Cindric, L.P. Frketic, M. Vertzoni, B. Cetina-Cizmek and C. Reppas, J. Chromatogr. Sci., 48, 114 (2010).

5. B. Dhanya, A. Suganthi, A.K. Sen, U. Sahoo and A.K. Seth, J. Pharm. Sci., 73, 120 (2011).

6. R.T. Sane, M. Francis, P.S. Hijli, S. Pawar and A.R. Pathak, J. Planar Chromatogr., 15, 34 (2012).

7. G. Altiokka and Z. Atkosa, J. Pharm. Biomed. Anal., 27, 841 (2002).

8. G. Altiokka and M. Tuncel, J. Pharm. Biomed. Anal., 17, 169 (1998).

9. H.P. Latha and G.V. Sagar. Der. Pharm. Res., 4, 1642 (2011).

10. L.I. Bebawy, A.A. Moustafa and N.F. Abo-Talib, J. Pharm. Biomed. Anal., 27, 779 (2002).

11. Z. Aydogmus and A. Barla, J. AOAC Int., 92, 131 (2009).

12. A.M. El-Brashy, M.E.S. Metwally and F.A. El-Sepai, IL Farmaco, 59, 809 (2004).
13. F. Belal, A. El-Brashy, N. El-Enany and N. El-Bahay, J. AOAC Int., 91, 1309 (2008).

14. M. Walash, F. Belal, M. Eid and S.A. Abass, J. Fluoresc., 21, 555 (2011).

15. A.F.M. El Walily, S.F. Belal and R.S. Bakry, J. Pharm. Biomed. Anal., 14, 561 (1996).

16. K. Kelani, L.I. Bebawy and L. Abdel-Fattah, J. Pharm. Biomed. Anal., 18, 985 (1999).

17. J. Rose, Advanced Physico-Chemical Experiments, Pitman, London, p. 54 (1964).

18. P. Job, Spectrochemical Methods of Analysis, Wiley Interscience, New York, p. 346 (1971).

19. J.E. Conte Jr., G. Wang, E.T. Lin and E. Zurlinden, J Chromatogr. B: Biomed. Sci. Appl., 753. 343 (2001).

20. ICH, Q 2(R1); Validation of Analytical Procedures: Text and Methodo-logy, International Conference on Harmonization, Geneva (2005).

21. J.N. Miller and J.C. Miller, Statistics and Chemometrics for Analytical Chemistry, Pearson Education Limited, Harlow, edn 5 (2005).

22. P. Gomes and M. Steppe, J. AOAC Int. 89, 1296 (2006). 